\title{
Assessment of Bacterial Contamination of Dried Herbs and Spices Collected from Street Markets in Dhaka
}

\author{
Farjahan Nur, Ummay Kulsum Libra, Prova Rowsan, Md. Abul Kalam Azad \\ and Kohinur Begum
}

Department of Pharmacy, ASA University Bangladesh, Dhaka-1207, Bangladesh

(Received: 15 February, 2018; Accepted: 14 April, 2018; Published: 31 July, 2018)

\begin{abstract}
Crude plant parts used as a source of medicine is an ancient practice and important for health care system worldwide. In Bangladesh, a large number of population depends on the traditional medicine using crude drugs. In traditional systems, street sellers collect powered plant parts or dried plant parts from whole sale markets locally or from various parts of Bangladesh. Favorable environmental condition for microbial growth and handling with unhygienic conditions may result in microbial contamination. The present study was performed to assess the total bacterial count and presence of coliform bacteria from 33 powdered plant part samples collected from street markets, Dhaka. Bacterial count was performed using pour plate technique in nutrient agar according to microbiological standard USP method. Bacterial growth was done by streak plate technique on MacConkey and EMB agar plates. Results showed that, 13 out of 33 samples exceeded permissible limit of bacterial count $\left(>10^{5} \mathrm{cfu} / \mathrm{gm}\right)$. However, 20 samples showed bacterial count ranging from $3.1 \times 10^{2}$ to $2 \times 10^{3} \mathrm{cfu} / \mathrm{gm}$. About $48.5 \%$ samples contained Escherichia coli indicating the presence of coliform bacteria and $21.2 \%$ samples contained other enteric bacteria (unidentified) which was confirmed by bacterial growth on MacConkey and EMB agar plates. Therefore, from this study, it may be concluded that crude herbal products contain a high level of bacteria that may be associated with health risk.
\end{abstract}

Key words: Herbs, spices, bacterial count, coliform bacteria.

\section{Introduction}

Herbs and spices are used for their flavors, colors and aromas and are widely used for food preparation and processing throughout the world from the ancient time. Crude plant parts and herbs are also used for different medicinal purposes like home health care, health improvement, as alternative medicines in many countries worldwide (Nikajima et al., 2005). Herbal drugs are crude products of medicinal plants. They are either dried plant or any part of plants such as leaf, stem, root, flower or seed. Apart from traditional medicine systems, they are important elements in ayurvedic, homeopathic, naturopathic, traditional Chinese medicine and American medicine (Sofowora, 1994). According to World Health Organization (WHO) survey, approximately 70-80\% of the world population specially of the developing countries highly depend on herbal medicines for their primary healthcare (WHO, 1998). Uses of herbal medicines in India, China, Egypt, Greece, Roman and Syria are recorded about 5000 years ago (Zhang et al., 2007). Although the uses of herbal drugs were confined to developing countries, its uses also gain popularity throughout the developed world for primary healthcare because of their efficacy, safety and lesser side effects (Kamboj, 2000). Microbial contaminations of spices and herbs were reported during pre- and post-harvest as well as processing, storage, distribution, sale and/or use (McKee, 1995). It has also been reported that spices are heavily contaminated with xerophilic storage moulds and bacteria (Romagnoli et al., 2007).

The people of Bangladesh specially in rural and tribal areas are highly dependent on different crude

Correspondence to: Kohinur Begum; Email: prof.kohinur@asaub.edu.bd; kohinur025@yahoo.com 
plant parts for primary treatment. Our environment is favorable for microbial growth which may enhance chances of contamination leading to spoilage of the products. Uses of contaminated products may cause serious health problems. So it is essential to maintain the microbial quality in crude products. In Bangladesh, there is no such valid data for microbiological assessment of the herbs and spices as per our knowledge. The present study was designed to assess the total bacterial count and presence of coliform bacteria in herbs and spices collected from street markets of Dhaka.

\section{Materials and Methods}

Sample collection: Total 33 samples of different spices and herbs were collected from open markets of different parts of Dhaka city, Bangladesh. $100 \mathrm{~g}$ of powder of each sample were collected in sterilized polyethylene bags and stored at $4^{\circ} \mathrm{C}$ until use.

Bacterial count test: Bacterial count was performed by using pour plate technique according to microbiological standard USP method. Shortly, one gram powdered sample was added in $9 \mathrm{ml}$ of sterile peptone water to get ten folds dilution of original sample. Samples were incubated for 3 hours at $37^{\circ} \mathrm{C}$ and $1 \mathrm{ml}$ was added into petridish followed by addition of molten nutrient agar (NA) having temperature around $40^{\circ} \mathrm{C}$. Then petridishes were rotated to distribute the sample uniformly in the media. Media on the petridishes were allowed to solidify and then the plates were incubated at $37^{\circ} \mathrm{C}$ for $48 \mathrm{hrs}$. Duplicate plates were inoculated for each sample. Average bacterial count was calculated. At the end of the incubation period, all of the petri plates containing between 30 and 300 colonies are selected. Plates with less than 30 and more than 300 colonies were not considered for counting. Number of bacteria (CFU) per gm were calculated.

Identification of coliform bacteria: Identification of coliform bacteria was done by using MacConkey and eosin methylene blue (EMB) agar media. Suspected single colony was sub cultured from nutrient agar plate on MacConkey and EMB agar plate and incubated at $37^{\circ} \mathrm{C}$ for 24 hours. Then presence of characteristics bacteria was observed. Bacteria were primarily identified by morphological study such as appearance of colony texture, shape, pigment and growth pattern in MacConkey and EMB agar plate.

\section{Results and Discussion}

Total $13(39.4 \%)$ out of 33 samples exceeded permissible limit of bacterial count $\left(>10^{5} \mathrm{cfu} / \mathrm{gm}\right)$. However, $20(60.6 \%)$ samples showed bacterial count ranging from $3.1 \times 10^{2}$ to $2 \times 10^{3} \mathrm{cfu} / \mathrm{gm}$ (Table 1 and Figure 1). $48.5 \%$ samples contained Escherichia coli indicating the presence of coliform bacteria and $21.2 \%$ samples contained other enteric bacteria (unidentified) (Table 2 and Figure 2). On the other hand, $30.3 \%$ samples did not show any bacterial growth on MacConkey and EMB agar plates.

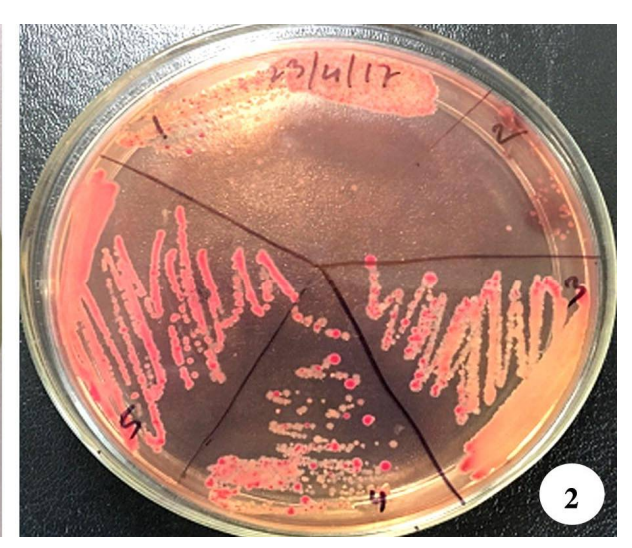

Figures 1-2. 1. Observation of bacterial count. 2. Bacterial growth on MacConkey agar plate. 
Table 1. Bacterial count of herbs and spices.

\begin{tabular}{clll}
\hline Sample no. & Plant name & Scientific name & Bacterial count $(\mathrm{cfu} / \mathrm{g})$ \\
\hline 1 & Coriandar seed & Coriandrum sativum & $12.9 \times 10^{2}$ \\
2 & Haritaki & Tarminalia chebula & $12.6 \times 10^{2}$ \\
3 & Cumin seed & Cuminum cyminum & $>10^{5}$ \\
4 & Bahara & Terminalia bellirica & $13.7 \times 10^{2}$ \\
5 & Chilli & Capsicum annum & $13 \times 10^{2}$ \\
6 & Indian -gooseberry & Phyllanthees emblica & $6.0 \times 10^{2}$ \\
7 & White- mustard & Sinapis alba & $11.7 \times 10^{2}$ \\
8 & Black-mustard & Brassica nigra & $6.2 \times 10^{2}$ \\
9 & Black-caraway & Nigella sativa & $>10^{5}$ \\
10 & Clove & Syzyium aromaticum & $3.5 \times 10^{2}$ \\
11 & Cardamom & Elettaria cardamomum & $2 \times 10^{3}$ \\
12 & Cinnamon & Cinnamomum verum & $3.6 \times 10^{2}$ \\
13 & Nutmug & Myristica fragrans & $3.1 \times 10^{2}$ \\
14 & Black pepper & Piper nigrum & $>10^{5}$ \\
15 & Turmeric & Curcuma longa & $>10^{5}$ \\
16 & Arjun & Terminalia arjuna & $3.9 \times 10^{2}$ \\
17 & Vetiver & Chrysopogon zizanioides & $>10^{5}$ \\
18 & Fenugreek seed & Trigonella foenumgraccum & $3.3 \times 10^{2}$ \\
19 & Bael & Aegle marmeles & $>10^{5}$ \\
20 & Swertia & Swertia charayita & $13 \times 10^{2}$ \\
21 & Liquorice & Glycyrrhiza aromaticum & $>10^{5}$ \\
22 & Senna & Cassia angustifolia & $7.7 \times 10^{2}$ \\
23 & Garden cress & Lepidium sativum & $3.7 \times 10^{2}$ \\
24 & Ispaghul & Plantago ovata & $>10^{5}$ \\
25 & Ajwain & Trachyspermum ammi & $>10^{5}$ \\
26 & Ashwagandha & Withania somnifera & $>10^{5}$ \\
27 & Mango & Mangifera indica & $>10^{5}$ \\
28 & Jambul & Syzygium cumini & $1.5 \times 10^{3}$ \\
29 & Bombax & Bombax ceiba & $>10^{5}$ \\
30 & Common fig & Ficus carica & $>10^{5}$ \\
31 & Tamarind & Tamarnidus indica & $1.6 \times 10^{3}$ \\
32 & Sesame & Sesamum indicum & $3.1 \times 10^{2}$ \\
33 & Linseed & Linum utitatissimum & \\
\hline & & & \\
\hline
\end{tabular}

Herbs and spices are used in foods as well as in various treatments throughout Bangladesh. Collection, handling, storage, selling of herbs and spices are great sources for bacterial contamination because they are not properly performed. Presence of bacterial contamination can lead to severe problems that results increased number of food-borne infections and intoxications (Buckenhüskes and Rendlen, 2004). Although herbs are traditionally utilized for medical treatments, some of their biological activities are scientifically characterized (Itharat et al., 2004; Murakami et al., 1995; Yoosook et al., 2000). In this study, an attempt has been taken for determination of bacterial count and presence of 
coiliform bacteria. The results obtained from this study were compared with USP standard. Results have shown that near about $40 \%$ samples exceeded permissible limit of bacterial count $\left(>10^{5} \mathrm{cfu} / \mathrm{gm}\right)$ (Table 1 and Figure 1). 48.5\% samples contained Escherichia coli that indicated the presence of coliform bacteria. Also, a little higher than 21\% samples were contaminated with other unidentified enteric bacteria (Table 2 and Figure 2). These contaminations might occur due to improper condition of collection, storage and selling of these

Table 2. Identification for presence of coliform bacteria.

\begin{tabular}{|c|c|c|c|}
\hline $\begin{array}{c}\text { Sample } \\
\text { no. }\end{array}$ & Plant name & $\begin{array}{c}\text { Growth on } \\
\text { MacConkey agar }\end{array}$ & Growth on EMB agar \\
\hline 1 & Coriandar seed & g+ & g+ \\
\hline 2 & Haritaki & $\mathrm{g}$ & $\mathrm{g}$ \\
\hline 3 & Cumin seed & g+ & g+ \\
\hline 4 & Bahara & g+ & g+ \\
\hline 5 & Chilli & g+ & g+ \\
\hline 6 & Indian -gooseberry & - & - \\
\hline 7 & White- mustrud & $\mathrm{g}$ & g \\
\hline 8 & Black-mustrud & g+ & g+ \\
\hline 9 & Black-caraway & g+ & g+ \\
\hline 10 & Clove & - & - \\
\hline 11 & Cardamom & - & - \\
\hline 12 & Cinnamon & - & - \\
\hline 13 & Nutmug & - & - \\
\hline 14 & Black pepper & $\mathrm{g}$ & $\mathrm{g}$ \\
\hline 15 & Turmeric & $\mathrm{g}$ & $\mathrm{g}$ \\
\hline 16 & Arjun & g+ & g+ \\
\hline 17 & Vetiver & - & - \\
\hline 18 & Fenugreek seed & g+ & $g+$ \\
\hline 19 & Bael & g+ & g+ \\
\hline 20 & Swertia & g+ & g+ \\
\hline 21 & Liquorice & $\mathrm{g}$ & $\mathrm{g}$ \\
\hline 22 & Senna & g+ & $g+$ \\
\hline 23 & Garden cress & - & - \\
\hline 24 & Ispaghul & $\mathrm{g}$ & $\mathrm{g}$ \\
\hline 25 & Ajwain & - & - \\
\hline 26 & Ashwagandha & g+ & g+ \\
\hline 27 & Mango & g+ & g+ \\
\hline 28 & Jambul & - & - \\
\hline 29 & Bombax & g+ & g+ \\
\hline 30 & Common fig & $\mathrm{g}$ & $\mathrm{g}$ \\
\hline 31 & Tamarind & g+ & g+ \\
\hline 32 & Sesame & g+ & g+ \\
\hline 33 & Linseed & - & - \\
\hline
\end{tabular}

$\mathrm{g}+=$ bacterial growth $($ E. coli), $\mathrm{g}=$ bacterial growth (unidentified), - = negative growth 
samples. It may also be caused due to suitable bacterial growth condition in our environment. It has been reported that bacterial contamination occurred due to variations in cultivation, production conditions, contaminated raw materials and processing (Schweiggert et al., 2007; Esimone et al., 2002). So, it is very essential to maintain the product quality because product quality is the main criteria that could affect the efficacy as well as safety of consumers (Jutaputti, 2001).

\section{Conclusion}

From this study it is concluded that herbs and spices collected from street markets contain a high level of bacterial count that may be associated with health risk. This was our preliminary study and further study is in progress to investigate in wide scale to identify the presence of specific bacteria.

\section{References}

Buckenhüskes, H.J. and Rendlen, M. 2004. Hygienic problems of phytogenic raw materials for food production with special emphasis to herbs and spices. Food Sci Biotechnol. 13, 262-268.

Esimone, C.O., Oleghe, P.O., Ibezim, E.C. and Okeh, C.O. 2007. Susceptibility-resistance profile of microorganism isolated from the herbal medicine products sold in Nigeria. African J. Biotechnol. 6, 2766-2775.

Itharat, A., Houghton, P.J., Eno-Amoo- quaye E., Burke P.J., Sampson J.H. and Raman A. 2004. In vitro cytotoxic activity of Thai medicinal plants used traditionally to treat cancer. J Ethnopharmacol. 90, 33-38.
Jutaputti A. 2001. The development of the quality of Thai herbal products for global market. Bull. Dept. Med. Scie. 43, 71-84

Kamboj, V.P. 2000. Herbal Medicine. Current Science. 78, 35 .

McKee, L.H. 1995. Microbial contamination of spices and herbs: areview. Lebensm. Wiss. Technol. 28, 1-11.

Murakami A., Jiwajinda S., Koshimizu K. and Ohigashi, H. 1995. Screening for in vitro anti-tumor promoting activities of edible plants from Thailand. Cancer Lett. 95, 139-146.

Nikajima, K., Nonaka, K., Yamamoto, K., Yamaguchi, N., Tani, K. and Nasu, M. 2005. Rapid monitoring of microbial contamination on herbal medicines by fluorescent staining method. Lett. Appl. Microbiol. 40, 128-132.

Romagnoli, B., Menna, V., Gruppioni, N. and Bergamini, C. 2007. Aflatoxins in spices, aromatic herbs, herbs teas and medicinal plants marketed in Italy. Food Control. 18, 697-701.

Schweiggert, U., Carle R. and Schieber, A. 2007. Conventional and alternative processes for spice production - a review. Trends Food Sci Technol. 18, 260-268.

Sofowora, E.A. 1994. Medical plant and Traditional Medicine in Africa. University of Ife Press, Nigeria.

World Health Organization (WHO). 1998. Regulatory situation of herbal medicines: A world wide review, World Health Organization, Geneva.

Yoosook C., Bunyapraphatsara N., BoonyakiatY. and Kantasuk C. 2000. Anti-herpes simplex virus activities of crude water extracts of Thai medicinal plants. Phytomedicine. 6, 411-419.

Zhang, M., Liu, X., Li, J., He L. and Tripathy, D. 2007. Chinese medicinal herbs to treat the side-effects of chemotherapy in breast cancer patients. Cochrane Database Syst. Rev. 2, CD004921. 